\title{
Chapter 6 \\ Shadow Economy in the Business \\ and Entrepreneurial Sectors
}

\author{
Gorana Krstić and Branko Radulović
}

\subsection{Assessment of Main Types of the Shadow Economy and Their Characteristics}

Research to date on the shadow economy in South Eastern Europe and beyond has mainly focused on macro assessments of this phenomenon or on the socioeconomic characteristics of individuals involved in these activities. There have been far fewer studies analysing the characteristics of businesses engaged in the shadow economy and the factors that drive them to operating informally. Exceptions are research on the shadow economy in Bulgaria and the Baltic States (Estonia, Lithuania, and Latvia) based on data from the survey of businesses operating informally, and a study on the impact of the shadow economy on the operation and competitiveness of businesses in South Eastern Europe, based on data from the Business Environment and Enterprise Performance Study (BEEPS) (Kyle et al. 2001; Williams 2006; Tedds 2010; Putninš and Sauka 2011; Hudson et al. 2012).

G. Krstić $(\bowtie)$

Faculty of Economics, University of Belgrade, Belgrade, Serbia

e-mail: gkrstic@ekof.bg.ac.rs

B. Radulović

Faculty of Law, University of Belgrade, Belgrade, Serbia

e-mail: bradulovic@ius.bg.ac.rs 


\section{Definition of the Shadow Economy and Informal Employment in the Survey on Conditions for Doing Business in Serbia}

Business entities engaged in the shadow economy are those that employ workers informally and/or make payments in cash as VAT payers. The term 'informally employed' refers to those workers who are either employed without a formal contract, or who do have a contract but only a portion of their wages is declared, meaning that they receive a portion of their pay in cash.

The findings of the Survey on Conditions for Doing Business in Serbia carried out for the purposes of this study show that $28 \%$ of all business entities in Serbia engage in activities in the shadow economy (Table 6.1), while one-fifth of all business entities employ workers informally.

If we include the other two categories-workers employed through the youth employment agency and non-VAT payer entrepreneurs contracted to perform certain activities for a company instead of its regular permanent employees with the aim of cutting costs or securing cash (at a $10 \%$ commission) — the percentage of businesses engaging in shadow economy activities would be substantially greater, reaching $32.2 \%$. Although these two categories most often represent informal practices, they are not included in our basic definition of the shadow economy, as the survey did not include questions we could use to estimate how informal they actually are. Thus, for the purposes of this analysis, we have used a narrower definition. Nonetheless, regardless of the definition we use, the ratio of business entities in the shadow economy to the total number of business entities is relatively high, particularly in light of the fact that this figure presents the lower limit of the observed phenomenon, due to respondents' inclination to disguise their informal activities.

Table 6.1 shows the share of business entities in the shadow economy in the total number of business entities by their basic characteristics. According to the findings of the survey, the share of business entities evading VAT is slightly higher (one-quarter of all VAT payers) than the share of those engaging in informal employment (one-fifth of the total number of business entities).

When the results are viewed by type of business entity, it can be seen that entrepreneurs are more involved in the shadow economy than businesses $(30.7 \%$ as against $23 \%$, respectively), since informal employment and VAT evasion are more frequent with entrepreneurs than with businesses. It is also evident that new businesses and entrepreneurs, i.e., those registered after 2009, are more likely to engage in the shadow economy than older businesses. This is primarily the result of their inclination to employ workers without formal contracts, or with contracts but without declaring their entire wages. On the other hand, no differences are visible when it comes to informal transactions. This type of employment can be explained by the fact that start-ups use it in an endeavour to cut their costs and improve competitiveness. 
Table 6.1 Percentage of business entities involved in the shadow economy, by characteristics

\begin{tabular}{|c|c|c|c|c|}
\hline & $\begin{array}{l}\% \text { of business } \\
\text { entities in the } \\
\text { shadow } \\
\text { economy }\end{array}$ & $\begin{array}{l}\% \text { of business } \\
\text { entities } \\
\text { employing } \\
\text { workers } \\
\text { informally }\end{array}$ & $\begin{array}{l}\% \text { of VAT paying } \\
\text { business entities } \\
\text { making payments } \\
\text { in cash }\end{array}$ & $\begin{array}{l}\% \text { of business } \\
\text { entities engaging in } \\
\text { both types of } \\
\text { shadow economy }\end{array}$ \\
\hline Total & 28.4 & 20.5 & 24.5 & 5.7 \\
\hline \multicolumn{5}{|c|}{ Type of business entity } \\
\hline Business & 23.0 & 14.5 & 18.3 & 6.4 \\
\hline Entrepreneur & 30.7 & 23.0 & 29.2 & 5.4 \\
\hline \multicolumn{5}{|l|}{ Age } \\
\hline $\begin{array}{l}\text { Start-up, 1-2 } \\
\text { years }\end{array}$ & 32.1 & 26.5 & 24.7 & 7.3 \\
\hline Others & 27.9 & 19.6 & 24.8 & 5.5 \\
\hline \multicolumn{5}{|c|}{ Number of employees } \\
\hline Up to 4 & 27.7 & 20.2 & 25.7 & 5.2 \\
\hline $5-19$ & 32.8 & 23.6 & 22.0 & 9.1 \\
\hline $20-49$ & 28.0 & 11.4 & 24.8 & 6.5 \\
\hline $50-249$ & 24.5 & 16.9 & 15.8 & 7.7 \\
\hline 250 and above & 31.4 & 31.4 & 0.0 & 0.0 \\
\hline \multicolumn{5}{|l|}{ Sector of activity } \\
\hline Agriculture & 33.8 & 20.0 & 25.3 & 3.4 \\
\hline Industry & 27.5 & 20.2 & 24.8 & 7.3 \\
\hline Construction & 42.9 & 32.7 & 42.3 & 11.6 \\
\hline Trade & 24.9 & 15.0 & 20.8 & 6.3 \\
\hline Transportation & 32.7 & 23.8 & 41.6 & 4.8 \\
\hline Catering & 33.1 & 22.4 & 30.8 & 2.8 \\
\hline Other services & 25.0 & 21.4 & 17.4 & 3.2 \\
\hline \multicolumn{5}{|l|}{ Region } \\
\hline Vojvodina & 25.6 & 19.8 & 18.8 & 4.3 \\
\hline Belgrade & 24.7 & 16.2 & 20.2 & 3.8 \\
\hline $\begin{array}{l}\text { Serbia excl. } \\
\text { Belgrade }\end{array}$ & 33.0 & 24.1 & 31.8 & 8.0 \\
\hline
\end{tabular}

Source: Own calculations. Survey on Conditions for Doing Business in Serbia, FREN, 2012

When businesses are disaggregated by sector of economic activity, most business entities active in the shadow economy are seen to be operating in the construction sector $(42.9 \%)$, followed by agriculture $(33.8 \%)$, catering $(33.1 \%)$ and transportation (32.7\%). Similar results were obtained by Schneider (2011a), who studied six European countries (Turkey, Spain, Italy, Germany, Poland, and Romania and found that the shadow economy was at its most pronounced in the construction sector (about $30 \%$ of the total number of sector employees), the wholesale and retail trade, catering, and transportation. A study of businesses in the Baltic States (Putninš and Sauka 2011) also found that the shadow economy was predominant in the construction sector, followed by services and retail trade, sectors of activity traditionally favourable for shadow economy activities. 
Both components of the shadow economy-informal employment and transactions - are at their most pronounced in the construction sector. Approximately one-third of all business entities in the construction sector have informal workers, while $42.3 \%$ of VAT payers engage in shadow transactions. If we consider all types of work, we can see that construction workers are most often engaged without a formal employment contract, through the intermediation of an entrepreneur, with a contract but with a portion of their wage undeclared, or under a temporary service agreement. All of these forms of work are present in construction to an aboveaverage degree in relation to other sectors of activity. It is interesting to note that all construction businesses employing between 5 and 19 people included in our sample engaged in the shadow economy.

Underreporting of income is particularly noticeable in the construction sector, mainly in the sub-contracting process and in activities that are directly related to the population. In these activities, cash generated from the sale of a company's products can be used to pay suppliers, reducing both income derived from such sales and costs. Although the reduction in costs is not particularly useful, goods and services can be bought much more cheaply, as suppliers are able to evade paying VAT.

Many construction companies operate, on average, for very brief periods of time, up to two or three years, obtain some government contracts through public procurement procedures, and then vanish from the market. A significant number of these firms are actually intermediaries between the client and the sub-contractors, earning between 10 and $50 \%$ of the contract price in commissions. These practices could be avoided if public procurement tenders were open only to companies with substantial references, an established number of permanent workers, and an annual turnover not lower than the value of the public procurement contract (SocioEconomic Council of the Republic of Serbia 2010).

After construction, the sectors with the highest proportion of activity in the shadow economy are agriculture, catering, and transportation $(33.8,33.1$, and $32.7 \%$, respectively). According to Schneider (2011b), in these sectors, with the exception of agriculture, most income is under reported due to cash transactions.

The large percentage of business entities in the agriculture sector engaged in the shadow economy-mainly entrepreneurs with few employees-makes it impossible for these businesses to obtain government subsidies or to borrow to finance current operations or improve production. Most of them are smallholdings with low production volumes, and this means that they cannot develop their businesses and raise living standards.

Apart from catering, where a large shadow economy is expected, the shadow economy is also extensive in the transportation sector. There are several explanations for this. Transportation businesses are small compared to other sectors of economic activity, and are more able to operate informally. However, although transportation ranks second to construction in the share of businesses in the VAT system that make cash payments (41.6\%), it needs to be underlined that the amount of VAT actually evaded is minimal (Table 6.3), as the share of cash transactions in the total volume of payments is the lowest of any sector (a mere $4.8 \%$ ). Similarly, in catering the share of VAT payers engaged in cash transactions is above average 
(30.8\%), while the percent of VAT avoided is below average. Finally, based on the results of the survey, it seems that transportation businesses are subject to less inspection than other sectors. However, businesses in trade are frequently subject to inspection, so part of the explanation for their lower share in the informal economy is due to a higher probability of detection. There are other explanations for the lower share of the shadow economy in trade: for example, the increasing share of large chains in the retail sector.

The typical link between the shadow economy and the size of the business, whereby businesses with fewer workers are more likely to engage in the shadow economy (Rice 1992; Hanlon et al. 2007; Tedds 2010; Williams 2006), is not as pronounced in Serbia. The shadow economy is mainly the domain of businesses with between 5 and 19 employees and large businesses with 250 or more employees. These businesses are over-represented as regards informal employment, while micro-businesses with up to five workers and medium-sized businesses (50-249 workers) are over-represented among VAT payers as regards cash payments.

Such substantial participation of business entities employing between 5 and 19 workers in the shadow economy can be explained by the large share of small construction firms and entrepreneurs who take part in the shadow economy (70\% of the total number of businesses in this group). Some $60 \%$ of them employ workers informally; $45 \%$ of them engage in cash payments. On the other hand, nearly one-third of all large businesses (with 250 or more staff) are involved in the shadow economy: their participation is manifested through informal employment, with above-average participation by state-owned businesses and below-average participation by private businesses (36\% and compared to $27 \%$, respectively).

When the data are viewed by region, business entities based in Central Serbia (excluding Belgrade) are the most likely to engage in the shadow economy, while those in Belgrade are least likely (33\% vs. $24.7 \%$ ). A similar difference can be observed when looking at type of shadow economy activity. Business entities from Central Serbia dominate in informal employment and informal transactions (VAT paying business entities making payments in cash) compared to businesses in Belgrade where informal employment is the least pronounced or to Vojvodina where informal payment is the least pronounced. We will see in next section, where we analyze the determinants of shadow economy participation, if these regional differences in shadow economy participation remain when the impact of business size, sector of economic activity, etc. is controlled for.

The last column of Table 6.1 shows that only $5.7 \%$ of business entities practise both types of informal activities i.e., have informal workers and engage in informal transactions. This subset of the basic set of business entities involved in the shadow economy has similar features to the basic set. Businesses as opposed to entrepreneurs, business entities employing between 5 and 19 workers, start-ups, construction firms, and those based in Central Serbia are most likely to engage in both types of shadow economy.

We will analyse two additional indicators of the shadow economy. These are the share of informal workers in the total number of workers (both overall and by type), 
Table 6.2 Comparison of respondents' views on the participation of their own and other businesses in the shadow economy

\begin{tabular}{l|l|l}
\hline & $\begin{array}{l}\text { Participation of } \\
\text { businesses surveyed in } \\
\text { the shadow economy }\end{array}$ & $\begin{array}{l}\text { Respondents' subjective views on the } \\
\text { participation of businesses from the } \\
\text { same sector in the shadow economy }\end{array}$ \\
\hline $\begin{array}{l}\text { \% of workers without for- } \\
\text { mal contracts }\end{array}$ & 1.9 & 23.9 \\
\hline $\begin{array}{l}\text { \% of workers with formal } \\
\text { contracts but without fully } \\
\text { declared wages }\end{array}$ & 3.8 & 24.7 \\
\hline$\%$ of turnover in cash & 11.3 & 21.6 \\
\hline
\end{tabular}

Source: Own calculations. Survey on Conditions for Doing Business in Serbia, FREN, 2012

and the share of cash payments in total payments by basic characteristics of the business (Table 6.2).

The share of informally employed workers in the total number of workers is exceptionally low, amounting to $5.7 \%$, although one-fifth of all businesses claimed they had employed workers informally. This was caused by the respondents' twofold downward bias. Firstly, it can be assumed that a large number of respondents did not wish to admit they employed workers informally; secondly, one-quarter of those who did admit it did not wish to answer about the number of such workers and their earnings. Caution is thus needed when interpreting data about the share of informal employed in the total number of employed and their wages.

The share of employees whose wages are paid in cash $(3.8 \%)$ in the total number of those employed is greater than the share of those working without a formal contract $(1.9 \%)$. The share of workers paid 'envelope wages' was much lower in Serbia than in the five South Eastern European countries covered, along with other nations, in the 2007 Eurobarometer survey (Bulgaria, Cyprus, Greece, Romania, and Slovenia), where $16 \%$ of all workers, on average, receive 'envelope wages' (EC 2007). Much of this difference can certainly be attributed to the fact that the respondents in the Eurobarometer survey were aged 15 and over, with fewer incentives to disguise the activities of their employers than the employers themselves who were surveyed in Serbia.

However, this picture becomes very different when respondents' views on their own shadow economy practice are compared to their views on the shadow economy participation of other firms from the same sector. They considered all forms of the shadow economy to be represented to a much greater degree at 'other' businesses in the same sector than in their own businesses. Thus, as we have already underlined in Chap. 3, we consider data obtained from biased answers made by owners/managers on the participation of their own companies in informal operations as the lower limit of the extent of the shadow economy, while taking data collected from their subjective opinions on the participation of other businesses in the same sector as the upper limit. We can therefore say that the share of workers employed without a formal contract ranges from $1.9 \%$ (lower limit) to $23.9 \%$ (upper limit); the share of 
Table 6.3 Share of informal workers in total number of workers; share of cash payments in total payments, by company characteristics

\begin{tabular}{|c|c|c|c|c|}
\hline & $\begin{array}{l}\text { Informal } \\
\text { employment in } \\
\% \text { of total } \\
\text { employment }\end{array}$ & $\begin{array}{l}\% \text { of } \\
\text { workers } \\
\text { without } \\
\text { formal } \\
\text { contracts }\end{array}$ & $\begin{array}{l}\% \text { of workers with } \\
\text { formal contracts but } \\
\text { without fully declared } \\
\text { wages }\end{array}$ & $\begin{array}{l}\text { Cash payments as } \\
\% \text { of total } \\
\text { payments made by } \\
\text { VAT payers }\end{array}$ \\
\hline Total & 5.7 & 1.9 & 3.8 & 27.8 \\
\hline \multicolumn{5}{|c|}{ Type of business entity } \\
\hline Business & 3.5 & 1.0 & 2.5 & 22.6 \\
\hline Entrepreneur & 12.5 & 4.8 & 7.7 & 30.3 \\
\hline \multicolumn{5}{|l|}{ Age } \\
\hline $\begin{array}{l}\text { Start-up, 1-2 } \\
\text { years }\end{array}$ & 10.8 & 4.8 & 6.0 & 27.7 \\
\hline Others & 5.5 & 1.8 & 3.7 & 27.9 \\
\hline \multicolumn{5}{|c|}{ Number of employees } \\
\hline Up to 4 & 9.7 & 4.3 & 5.4 & 28.3 \\
\hline $5-19$ & 12.4 & 3.7 & 8.7 & 28.8 \\
\hline $20-49$ & 2.5 & 1.0 & 1.5 & 3.8 \\
\hline $50-249$ & 1.0 & 0.2 & 0.8 & 1.8 \\
\hline 250 and above & 2.7 & 0.5 & 2.2 & - \\
\hline \multicolumn{5}{|c|}{ Sector of activity } \\
\hline Agriculture & 7.9 & 3.9 & 4.0 & 31.0 \\
\hline Industry & 4.6 & 1.2 & 3.4 & 25.8 \\
\hline Construction & 5.2 & 3.0 & 2.2 & 43.0 \\
\hline Trade & 5.0 & 1.6 & 3.4 & 26.9 \\
\hline Transportation & 4.9 & 0.6 & 4.3 & 4.5 \\
\hline Catering & 8.4 & 1.5 & 6.9 & 13.8 \\
\hline Other services & 8.0 & 3.3 & 4.7 & 21.7 \\
\hline \multicolumn{5}{|l|}{ Region } \\
\hline Vojvodina & 5.3 & 2.8 & 2.5 & 30.2 \\
\hline Belgrade & 4.5 & 1.2 & 3.3 & 37.0 \\
\hline $\begin{array}{l}\text { Serbia excl. } \\
\text { Belgrade }\end{array}$ & 6.6 & 2.0 & 4.6 & 22.0 \\
\hline
\end{tabular}

Source: Own calculations. Survey on Conditions for Doing Business in Serbia, FREN, 2012

workers employed without their entire wages being declared ranges from 3.8 to $24.7 \%$; while the share of cash payments varies between 11.3 and $21.6 \%$.

According to the features of businesses (Table 6.3), the share of informal employment is greatest among entrepreneurs, start-ups one to two years old or less, companies employing between 5 and 19 workers, catering firms, other services, agriculture, and those based in Central Serbia. If we look at type of informal employment by sector of economic activity we see that agriculture, other services, and construction have the greatest share of those working without a formal contract, while the share of workers receiving 'envelope wages' is greatest in catering, other 
services, and transportation, which are also the sectors where it is easiest to sell goods and services for cash.

The share of cash payments in total payments made by VAT payers (both businesses and entrepreneurs) was $27.8 \%$. When disaggregated by business feature it is greater with entrepreneurs than with businesses; it is also the most pronounced in the smallest business entities, while no difference can be observed in terms of business age (Table 6.3). Cash payments are the most common in construction (43\%), where slightly less than half of all respondents $(42.3 \%)$ said they had made such payments (Table 6.1). Agriculture came next (31\%), with one-quarter of respondents reporting cash payments, followed by trade $(26.9 \%)$, where only six percent of all respondents reported having made payments in cash. When the data are viewed by region Belgrade is ahead of Vojvodina and Central Serbia with $37 \%$ of all payments made in cash, although the share of business entities making cash payments was greatest in Central Serbia (excluding Belgrade). These results lead to the conclusion that there is no major causal link between these two indicators of informal transactions: the share of business entities making payments in cash and the share of cash payments in total volume of payment transactions.

However, Table 6.4 shows a marked correlation between the various types of informal activity as cited by the business entities surveyed: in other words, when a business entity is involved in informal cash transactions it also has undeclared workers and unreported wage payments.

Slightly over half of all respondents cited purchase of goods as the main reason for paying in cash, nearly one-quarter reported paying cash for services, while the remainder cited using cash to pay wages and rent (Table 6.5). Goods and services are most often procured from entrepreneurs $(37.1 \%)$ and small or medium-sized businesses $(34.3 \%)$, and less frequently from large businesses or friends/family members (Table 6.6).

For some two-thirds of all respondents the principal reason for making cash payments was that they cost less; far fewer respondents cited better quality and inability to procure the required goods or services in the formal market (Table 6.7).

Nearly two-thirds of all respondents reported making payments in cash once a month, slightly over one-quarter claimed they did so once a week, while far fewer said they did so every day or once a year (Table 6.8). Daily cash payments were most common in trade, transportation, and other services. On average cash payments accounted for $22.9 \%$ of business entities' total costs/expenditure.

In view of these results, it can be concluded that the usual relationship between the shadow economy and the type, age, and sector of business exist in Serbia, with entrepreneurs, start-ups, and those in construction more likely to engage in shadow economy activity. However, the relationship between the shadow economy and business entity size whereby smaller businesses are more likely to participate in the shadow economy (Tedds 2010; Williams 2006) cannot be confirmed.

The wages of informal workers were lower than the wages of formal workers (those whose entire wage is paid via bank accounts). The wages of workers without formal contracts and workers who receive a portion of their wage in cash were lower than formal workers' wages by 51 and $28 \%$ respectively (Table 6.9). When 
Table 6.4 Correlation between types of informal activity

\begin{tabular}{l|l|l|l}
\hline & $\begin{array}{l}\text { \% of } \\
\text { undeclared } \\
\text { workers }\end{array}$ & $\begin{array}{l}\text { \% of workers with formal } \\
\text { contracts but without fully } \\
\text { declared wages }\end{array}$ & $\begin{array}{l}\text { \% of } \\
\text { wage paid } \\
\text { in cash }\end{array}$ \\
\hline $\begin{array}{l}\text { \% of workers with formal con- } \\
\text { tracts but without fully declared } \\
\text { wages }\end{array}$ & 0.75 & & \\
\hline$\%$ of wage paid in cash & 0.74 & 0.72 & 0.70 \\
\hline $\begin{array}{l}\text { \% of transactions carried out } \\
\text { informally (i.e., in cash) }\end{array}$ & 0.73 & 0.67 & \\
\hline
\end{tabular}

Source: Own calculations. Survey on Conditions for Doing Business in Serbia, FREN, 2012

Table 6.5 Most common reason for cash payments made by VAT payers

\begin{tabular}{l|c}
\hline & Total (\%) \\
\hline Purchase of goods & 52.4 \\
\hline Payment for services & 23.6 \\
\hline Payment of employee wages & 14.4 \\
\hline Payment of rent for premises & 0.1 \\
\hline Purchase of foreign currency intended for payment abroad & 9.6 \\
\hline Total & 100.0 \\
\hline
\end{tabular}

Source: Own calculations. Survey on Conditions for Doing Business in Serbia, FREN, 2012

Table 6.6 Who most often supplies the goods or services that you paid for in cash?

\begin{tabular}{l|c}
\hline & Total (\%) \\
\hline Friends/family members & 9.0 \\
\hline Other companies owned by respondent & 1.3 \\
\hline Entrepreneurs & 37.1 \\
\hline Small or medium-sized businesses & 34.3 \\
\hline Large businesses & 18.4 \\
\hline Total & 100.0 \\
\hline
\end{tabular}

Source: Own calculations. Survey on Conditions for Doing Business in Serbia, FREN, 2012

Table 6.7 Reasons for cash payments made by VAT payers

\begin{tabular}{l|c}
\hline & Total (\%) \\
\hline Lower price & 68.5 \\
\hline Better service & 12.8 \\
\hline Better quality & 4.3 \\
\hline Helping vulnerable social groups & 1.1 \\
\hline Doing favours to friends and family members & 4.4 \\
\hline Goods and services unavailable in the regular/formal market & 9.0 \\
\hline
\end{tabular}

Source: Own calculations. Survey on Conditions for Doing Business in Serbia, FREN, 2012 
Table 6.8 Frequency of cash payments made by VAT payers

\begin{tabular}{l|c}
\hline & Total (\%) \\
\hline Once every year & 3.2 \\
\hline Once every month & 62.4 \\
\hline Once every week & 27.4 \\
\hline Every day & 7.0 \\
\hline Total & 100.0 \\
\hline
\end{tabular}

Source: Own calculations. Survey on Conditions for Doing Business in Serbia, FREN, 2012

Table 6.9 Average net wages by type of work

\begin{tabular}{l|l}
\hline Type of work & $\begin{array}{l}\text { Net wage } \\
\text { (RSD) }\end{array}$ \\
\hline $\begin{array}{l}\text { Open-ended employment contract (entire wage paid via bank account) } \\
\begin{array}{l}\text { Open-ended employment contract (some money paid in cash in addition to } \\
\text { portion of wage paid via bank account) }\end{array}\end{array}$ & 38,061 \\
\hline Employment pursuant to a temporary service agreement & 27,277 \\
\hline Employment pursuant to a work for hire agreement & 25,752 \\
\hline Employment through a 'youth employment agency' & 22,847 \\
\hline Hiring an entrepreneur & 16,160 \\
\hline $\begin{array}{l}\text { Occasional/temporary work without a contract (trial work, training, } \\
\text { volunteering) }\end{array}$ & 23,401 \\
\hline
\end{tabular}

Source: Own calculations. Survey on Conditions for Doing Business in Serbia, FREN, 2012

the cost of taxes and contributions for those in formal employment are added to wages, the difference in labour costs between formal and informal workers is enormous. These findings are similar to those found by earlier research on the informal economy based on the Living Standards Measurement Study (Krstic and Sanfey 2011), which found that informal workers earned $44 \%$ less than formal workers, or $22 \%$ less when other characteristics of the workers are controlled for. Although the definition of informal employment was not the same in these two studies, it is evident that workers in the informal sector remain at a major disadvantage compared to those working in the formal sector.

The distribution of wages by business characteristics differs significantly between employees whose entire wage is paid through a bank account and the two types of informal employment (Table 6.10). While formal workers' wages are higher when paid by entrepreneurs, start-ups (established one to two years ago), businesses with over 20 employees, businesses in the industrial sector, and businesses in Central Serbia, the wages of workers without formal contracts are highest when paid by businesses, entities established two or more years ago, businesses employing between 5 and 19 workers, businesses engaged in trade, and businesses based in Vojvodina. 
Table 6.10 Average wages by type of work and business characteristics

\begin{tabular}{|c|c|c|c|}
\hline & $\begin{array}{l}\text { Permanent employees, entire } \\
\text { wage paid via bank account }\end{array}$ & $\begin{array}{l}\text { Permanent employees, } \\
\text { portion of wage paid in } \\
\text { cash }\end{array}$ & $\begin{array}{l}\text { Employees with } \\
\text { no formal } \\
\text { contracts }\end{array}$ \\
\hline Total & 38,061 & 27,277 & 19,261 \\
\hline \multicolumn{4}{|c|}{ Type of business entity } \\
\hline Business & 35,441 & 27,572 & 39,527 \\
\hline Entrepreneur & 39,337 & 27,187 & 16,953 \\
\hline \multicolumn{4}{|l|}{ Age } \\
\hline $\begin{array}{l}\text { Start-up, 1-2 } \\
\text { years }\end{array}$ & 65,054 & 36,060 & 15,904 \\
\hline Others & 35,937 & 25,539 & 18,185 \\
\hline \multicolumn{4}{|c|}{ No. of employees } \\
\hline Up to 4 & 37,879 & 26,759 & 16,118 \\
\hline $5-19$ & 33,787 & 28,830 & 21,542 \\
\hline 20 and over & 57,157 & 28,220 & 99,088 \\
\hline \multicolumn{4}{|c|}{ Sector of activity } \\
\hline Agriculture & 46,197 & 6,000 & - \\
\hline Industry & 55,128 & 23,923 & 20,525 \\
\hline Construction & 29,027 & 30,238 & 18,178 \\
\hline Trade & 37,243 & 24,904 & 29,390 \\
\hline Transportation & 29,353 & 24,210 & 20,000 \\
\hline Catering & 21,848 & 22,740 & 15,579 \\
\hline Other services & 35,781 & 35,470 & 14,585 \\
\hline \multicolumn{4}{|l|}{ Region } \\
\hline Vojvodina & 33,487 & 28,645 & 24,265 \\
\hline Belgrade & 38,241 & 32,757 & 17,312 \\
\hline $\begin{array}{l}\text { Serbia excl. } \\
\text { Belgrade }\end{array}$ & 40,890 & 23,339 & 17,753 \\
\hline
\end{tabular}

Source: Own calculations. Survey on Conditions for Doing Business in Serbia, FREN, 2012

\subsection{Determinants of Participation in the Shadow Economy}

In the previous section descriptive statistics were used to show how shadow economy activities varied by key factors. In this section we use econometric analysis to identify specific factors that are statistically significant in a company's decision to take part in the shadow economy.

Tax evasion literature usually identifies two groups of factors that affect a business's (or entrepreneur's) decision to participate in the shadow economy. ${ }^{1}$ The first group of factors relates to the model of the rational choice to engage in tax evasion. Entrepreneurs or businesses weigh the expected benefits and costs of

\footnotetext{
${ }^{1}$ For a concise recent survey of the literature on the informal economy and tax evasion, see Slemrod (2007).
} 
tax evasion and participation in the shadow economy, or, rather, compare the savings they stand to achieve through tax evasion and the costs in case they are caught. The expected costs depend on the likelihood of getting caught, the amount and type of the penalty, the likelihood of that penalty actually being imposed, and their propensity to risk. These factors differ by region, industry, and size and age of the business entity, and other factors.

The reason why empirical studies usually find that the real level of tax evasion is significantly lower than forecasts made using the rational choice model is the existence of a second group of factors: attitudes and social norms. In tax evasion literature these factors include the perception of the fairness of the tax system-the attitudes on the equity of the tax burden and procedures. As our assessment deals with attitudes regarding participation in the shadow economy, we examine how the decision to participate in the shadow economy depends on social norms, or, rather, moral values (as well as any feelings of guilt and stigma that may arise if the tax evader is caught). Finally, participation in the shadow economy can be temporary and the result of short-term operating difficulties, especially given the current economic crisis, which must also be taken into consideration.

In both literature and empirical studies, sanction probability plays a very significant role in explaining the causes of tax evasion (shadow economy). According to the results of the Survey on Conditions for Doing Business in Serbia (Fig. 6.1), the estimated probability of companies that operate informally being discovered is generally low. As many as $67 \%$ of the businesspeople surveyed believed that this probability was very low (i.e. that $50 \%$ or fewer companies operating informally would be caught). Just $17 \%$ of those surveyed thought that one in every two companies would be caught. Around $14 \%$ of those surveyed believed that one in three companies would be discovered; $13 \%$ thought that one in five businesses would be caught, while $14 \%$ believed this would happen to one in every ten. Such expectations support the decision to take part in the shadow economy because doing so significantly reduces expected expenses.

Furthermore, business entities' expectations of receiving fines for operating in the shadow economy were even lower. The survey results show that they believed it was very unlikely for the company manager or entrepreneur to be penalised if caught operating informally. Two-thirds of all business entities surveyed thought that there was a $50 \%$ or less chance of an entity or person operating in the shadow economy being penalised after getting caught, while $17 \%$ thought that one in every ten managers would face sanctions. The total probability of anyone who gets caught facing any sanctions is even lower, since as many as two-thirds $(67 \%)$ of the businesspeople surveyed thought that the fine imposed would be paid in fewer than $50 \%$ of all cases, while $17 \%$ felt that only one in every ten fines would be paid. Thus the likelihood that those who get caught actually are fined and pay that fine is believed to be very low. There are various ways in which business entities avoid paying their dues. According to the results of the survey the most common means of avoiding payment of a fine is corruption (40\%), followed by shifting the company's business to a newly established entity (17\%), or simply waiting for charges to lapse due to the operation of the statute of limitations $(18 \%)$. However, in our 


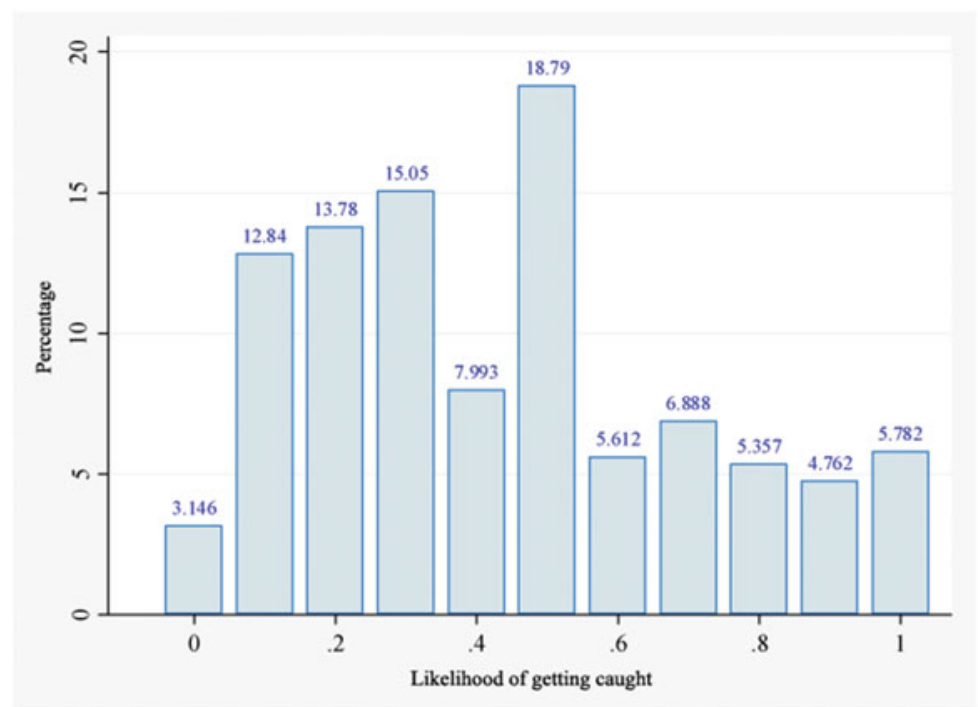

Fig. 6.1 Expectations of the likelihood of businesses not operating formally getting caught. Source: Own calculations. Survey on Conditions for Doing Business in Serbia, FREN, 2012

econometric analysis we focused on the simplest concept of expectations (how likely the respondents believed getting caught was if operating informally), mainly because some respondents may have misunderstood the question, which could mean that the calculation would result in unrealistically low expectations regarding the consequences of engaging in these activities.

Approximately two-thirds of all respondents thought that companies continued operating informally even after being fined for doing so. This result to some extent implies that the majority of respondents felt that fines were relatively mild. The majority of respondents $(46 \%)$ stated that fines for different types of informal operation should be increased. The attitude towards the severity of sanctions is very important for incentives, because if sanctions are perceived to be lax, business entities are more incentivised to take part in the shadow economy, or rather to evade taxes.

Finally, our analysis also examined attitudes toward the shadow economy itself; that is, whether the owners/managers considered informal operation to be justified. This factor can correlate with insincere answers, but we believe that it is still a good enough indicator of business entities' readiness to become active (or not) in the shadow economy in an environment where sanctions are less than likely. According to the results of the survey, over two-thirds (71\%) of all business entities thought that operating in this manner was unjustified. Just $17 \%$ were neutral, while $9 \%$ believed it to be justified. It is obvious that some business entities operating within the shadow economy were not being honest when they stated that informal operation was unjustified. The usual reasons cited when justifying informal operation were poor legal framework (46\%), competition from the informal sector (27\%), the great benefits of doing business in this manner $(27 \%)$, and the fact that almost all business entities engage in these practices ( $21 \%)$. 
We included certain other characteristics of business entities into our econometric analysis in addition to the factors already referred to. As has already been mentioned, nearly all recent start-ups are expected to be more involved in the shadow economy as tax evasion makes them more competitive, which is very important especially if they face obstacles when entering the market. Also, in order to consider the possible influence of the economic crisis, we used a proxy for the recent business results of the respondents based on their answers regarding trends in their total turnover (question A6). Poor performance is expected to affect a company's motivation to become active (or increase their participation) in the shadow economy.

Table 6.11 shows the results of econometric analysis of the determinants of participation in the shadow economy. The results presented in the table show the factors that affect the decision of a business entity to retain workers informally; that is, not to declare or to partially declare its employees in order to evade or reduce its tax burden (informal employment), and to make payments in cash even though it is a VAT payer. In other words, these factors affect the decision of whether to take part in the shadow economy (see Chap. 3).

Table 6.10 shows five logit models ${ }^{2}$ where the dependent variable represents broadly defined participation in the shadow economy (dependent variable: entity engages in activities in the shadow economy $[=1]$ or does not do so $[=0]) .{ }^{3} \mathrm{We}$ divided independent variables into five groups. The first group consisted of business entities' characteristics: business/entrepreneur, VAT payer, privately held or otherwise, share of foreign equity (variables presented as dummy variables), company age, and number of employees (a natural log transformed continuous variables). The second group consists of regional dummy variables. The third group consists of sector dummy variables. The fourth group is variables related to business entities' expectations and attitudes: the likelihood of detection and attitudes regarding the amount of fines and justification of the shadow economy. This group of variables was obtained on the basis of the opinions voiced by the respondents. Finally, the fifth group is made up of only one variable, turnover decline in 2010, and is used to establish whether deterioration in the economic position of the business entity influences the decision whether to take part in the shadow economy.

All models are statistically significant, and we will focus our attention, based on selection criteria, on the last model (5). The total number of observations for that model was 830 , fewer than for other models due to missing values. In the first group of independent variables, the binary variables of entrepreneur and VAT payer, as well as the logarithm (ln) of the number of employees (i.e., approximation of company size) are statistically significant. The other three variables-private

\footnotetext{
${ }^{2}$ Here we have shown the basic model only. The model does not contain interactions or other analysed variables.

${ }^{3}$ As the table shown contains different samples, we have not compared coefficients for the various models here (any explanation of the change in coefficients must also take into account the differences in sample size). For a detailed discussion, see Hosmer and Lemeshow (2000) and Long and Freese (2006).
} 
Table 6.11 Determinants of participation in the shadow economy

\begin{tabular}{|c|c|c|c|c|c|}
\hline & \multicolumn{5}{|l|}{ Model } \\
\hline & $(1)$ & (2) & $(3)$ & (4) & $(5)$ \\
\hline Entrepreneur & $\begin{array}{l}2.398 * * * \\
(3.91)\end{array}$ & \begin{tabular}{|l}
$2.348 * * *$ \\
$(3.78)$
\end{tabular} & $\begin{array}{l}2.417 * * * \\
(3.77)\end{array}$ & $\begin{array}{l}2.614 * * * \\
(3.48)\end{array}$ & $\begin{array}{l}2.611^{* * * *} \\
(3.46)\end{array}$ \\
\hline Business & $f$ & $f$ & $f$ & $f$ & $f$ \\
\hline VAT payer & $\begin{array}{l}1.949 * * * \\
(3.31)\end{array}$ & $\begin{array}{l}1.944 * * * \\
(3.30)\end{array}$ & \begin{tabular}{|l}
$2.317 * * *$ \\
$(3.91)$ \\
\end{tabular} & $\begin{array}{l}2.575^{* * * *} \\
(3.71) \\
\end{array}$ & \begin{tabular}{|l}
$2.639 * * *$ \\
$(3.76)$
\end{tabular} \\
\hline Non-VAT payer & $f$ & $f$ & $f$ & $f$ & $f$ \\
\hline Privately held & $\begin{array}{l}0.700 \\
(-0.69)\end{array}$ & \begin{tabular}{|l|}
0.683 \\
$(-0.73)$ \\
\end{tabular} & \begin{tabular}{|l|l|}
0.779 \\
$(-0.49)$ \\
\end{tabular} & $\begin{array}{l}0.507 \\
(-1.05)\end{array}$ & \begin{tabular}{|l|}
0.467 \\
$(-1.15)$ \\
\end{tabular} \\
\hline Other & $f$ & $f$ & $f$ & $f$ & $f$ \\
\hline Foreign equity & $\begin{array}{l}0.649 \\
(-0.63) \\
\end{array}$ & \begin{tabular}{|l|l}
0.645 \\
$(-0.64)$
\end{tabular} & \begin{tabular}{|l|l|}
0.650 \\
$(-0.69)$ \\
\end{tabular} & $\begin{array}{l}0.760 \\
(-0.44) \\
\end{array}$ & \begin{tabular}{|l|l|}
0.453 \\
$(-1.02)$ \\
\end{tabular} \\
\hline Non-foreign & $f$ & $f$ & $f$ & $f$ & $f$ \\
\hline $\ln ($ employees $)$ & $\begin{array}{l}1.596 * * * \\
(5.32)\end{array}$ & $\begin{array}{l}1.588^{* * * *} \\
(5.23)\end{array}$ & \begin{tabular}{|l}
$1.585^{* * * *}$ \\
$(4.99)$
\end{tabular} & $\begin{array}{l}1.674 * * * \\
(5.06)\end{array}$ & $\begin{array}{l}1.744 * * * \\
(5.38)\end{array}$ \\
\hline $\ln ($ age $)$ & $\begin{array}{l}0.960 \\
(-0.38)\end{array}$ & \begin{tabular}{|l}
0.962 \\
$(-0.35)$
\end{tabular} & \begin{tabular}{|l|}
0.985 \\
$(-0.14)$
\end{tabular} & $\begin{array}{l}0.898 \\
(-0.81)\end{array}$ & \begin{tabular}{|l|}
0.868 \\
$(-1.03)$ \\
\end{tabular} \\
\hline Belgrade & & $\begin{array}{l}1.066 \\
(0.28)\end{array}$ & $\begin{array}{l}1.064 \\
(0.26)\end{array}$ & $\begin{array}{l}0.966 \\
(-0.13)\end{array}$ & \begin{tabular}{|l|}
0.959 \\
$(-0.16)$
\end{tabular} \\
\hline Central Serbia & & $\begin{array}{l}1.204 \\
(0.84)\end{array}$ & $\begin{array}{l}1.253 \\
(1.02)\end{array}$ & $\begin{array}{l}1.169 \\
(0.60)\end{array}$ & $\begin{array}{l}1.124 \\
(0.45)\end{array}$ \\
\hline Vojvodina & & $f$ & $f$ & $f$ & $f$ \\
\hline Agriculture & & & $\begin{array}{l}2.227 \\
(1.15)\end{array}$ & $\begin{array}{l}2.297 \\
(1.26)\end{array}$ & $\begin{array}{l}1.694 \\
(0.72)\end{array}$ \\
\hline Industry & & & \begin{tabular}{|l}
0.847 \\
$(-0.56)$ \\
\end{tabular} & $\begin{array}{l}0.892 \\
(-0.33)\end{array}$ & \begin{tabular}{|l}
0.858 \\
$(-0.43)$ \\
\end{tabular} \\
\hline Construction & & & $\begin{array}{l}1.944 * * \\
(2.12)\end{array}$ & $\begin{array}{l}1.969 * \\
(1.82)\end{array}$ & $\begin{array}{l}1.887 * \\
(1.67)\end{array}$ \\
\hline Trade & & & $\begin{array}{l}0.696 \\
(-1.53)\end{array}$ & $\begin{array}{l}0.639 \\
(-1.64)\end{array}$ & \begin{tabular}{|l|l|}
$0.611^{*}$ \\
$(-1.81)$
\end{tabular} \\
\hline Transportation & & & $\begin{array}{l}1.675^{*} \\
(1.67)\end{array}$ & $\begin{array}{l}1.839 \\
(1.64)\end{array}$ & $\begin{array}{l}1.745 \\
(1.50)\end{array}$ \\
\hline Catering & & & $\begin{array}{l}.042 \\
(0.12)\end{array}$ & $\begin{array}{l}1.144 \\
(0.33)\end{array}$ & $\begin{array}{l}1.091 \\
(0.21)\end{array}$ \\
\hline Other services & & & $f$ & $f$ & $f$ \\
\hline Likelihood of getting caught & & & & $\begin{array}{l}1.735 \\
(1.50)\end{array}$ & $\begin{array}{l}1.772 \\
(1.56) \\
\end{array}$ \\
\hline $\begin{array}{l}\text { Attitude on shadow economy as a } \\
\text { justified response }\end{array}$ & & & & $\begin{array}{l}1.695 * * * \\
(5.95) \\
\end{array}$ & $\begin{array}{l}1.656^{* * * *} \\
(5.73)\end{array}$ \\
\hline $\begin{array}{l}\text { Attitude on penalties-penalties } \\
\text { seen as mild (Q D8) }\end{array}$ & & & & $\begin{array}{l}1.325 \\
(1.35)\end{array}$ & $\begin{array}{l}1.299 \\
(1.25)\end{array}$ \\
\hline Turnover decline since 2010 & & & & & $\begin{array}{l}1.213 \\
(0.92)\end{array}$ \\
\hline Wald chi ${ }^{2}$ (df) & $62.01(6)$ & $62.49(8)$ & $\begin{array}{l}79.97 \\
(14)\end{array}$ & $\begin{array}{l}105.8 \\
(17)\end{array}$ & $\begin{array}{l}108.5 \\
(18)\end{array}$ \\
\hline
\end{tabular}


Table 6.11 (continued)

\begin{tabular}{l|l|l|l|l|l}
\hline \multirow{2}{*}{} & \multicolumn{4}{l}{$l$} \\
\cline { 2 - 6 } & $(1)$ & $(2)$ & $(3)$ & $(4)$ & $(5)$ \\
\hline Pseudo ${ }^{2}$ a & 0.0592 & 0.0601 & 0.0781 & 0.145 & 0.148 \\
\hline $\mathrm{N}$ & 1,051 & 1,051 & 1,051 & 843 & 830 \\
\hline AIC & $1,141.8$ & $1,144.7$ & $1,135.1$ & 876.0 & 866.0 \\
\hline BIC & $1,176.5$ & $1,189.3$ & $1,209.5$ & 961.3 & 955.7 \\
\hline
\end{tabular}

Source: Own calculations. Survey on Conditions for Doing Business in Serbia, FREN, 2012

Notes: f-reference variable. AIC is the Akaike information criterion for model selection; BIC is the Bayesian information criterion, where the lower the value, the better the model. ${ }^{*} p<0.10$; $* * p<0.05 ; * * * p<0.01$

${ }^{\text {a }}$ Pseudo $\mathrm{R}^{2}$ or McFadden's likelihood ratio index compares the logarithm values of the likelihood functions for the intercept-only model and the model with the predictors (excluding all explanatory variables from the model). The value of this indicator ranges from 0 to 1 ; it resembles the linear model determination coefficient, but cannot be used as directly in interpreting results

ownership, foreign equity, and logarithm (ln) of company age — are not statistically significant, and for the sake of brevity will not be discussed further. ${ }^{4}$

We show results in terms of odds ratios. The odds ratio for entrepreneurs is 2.611. ${ }^{5}$ We interpret this as the odds of the entrepreneurs taking part in the shadow economy vs. the odds of the business's chance of doing so (while other independent variables remain unchanged). These results are in accordance with the findings of other studies, according to which entrepreneurs are more engaged in the shadow economy than other types of business (Tedds 2010; Williams 2006). We can interpret the VAT-payer coefficient in a similar manner. Finally, the significant variable belonging to the first group (denoting company size as expressed by the number of its staff) can be interpreted as follows: the odds ratio of an entity's participation in the shadow economy increases by 1.75 for each standard deviation of the increase in the ln of total employment (with all other variables unchanged). ${ }^{6}$ This finding is in accordance with the results of the descriptive analysis, which do not bear out the assumption that smaller companies are more prone to engaging in shadow economy activities. The difference from the usual result, according to

\footnotetext{
${ }^{4}$ As expected, the value of the coefficient for the age of company is smaller than one (with younger companies more likely to operate partially in the shadow economy). The same is true for the coefficient of business entities that operate wholly or in part with foreign equity.

${ }^{5} \mathrm{We}$ can here consider the ratio of the chance of a business owner taking part in the shadow economy to the chance of a company doing so. To illustrate this, let us provide the example of the model of $\mathrm{N}=1,000$ businesses and entrepreneurs, with 100 businesses taking part in shadow economy and 300 not doing so, and with 300 entrepreneurs participating in the shadow economy and 300 not doing so. The ratio calculated for businesses would amount to $(100 / 300) /(300 / 300)=$ 0.33 . The ratio for entrepreneurs would amount to 3 . It should be noted that a positive factor of 2 has the same effect size as a negative factor of 0.5. In other words, 2 is twice as great as 1 , while 0.5 is twice as small as 1 (the effect size is 2 in both cases). Based on this, we can conclude that, for instance, a coefficient of 0.1 is such that it has a greater effect than a coefficient of 2 .

${ }^{6}$ This result was obtained by using the listcoef command in Stata 11.1.
} 
which small businesses are more likely to participate in the shadow economy, can be partially explained by the fact that the definition of the shadow economy was to a large extent dependent on whether businesses employ workers outside the formal sector. The second reason is the fact that other studies use the value of assets or turnover to approximate company size. ${ }^{7}$

Interestingly, in all models regional characteristics are not statistically significant. In the third group, consisting of seven sector dummy-variables, businesses in the construction sector are nearly twice as likely to engage in shadow economy activities compared to other service sectors (in line with our expectations), while the trade sector, also statistically significant, was nearly twice as unlikely to take part in the shadow economy than the other service sectors. We should note that the remaining sectors also had the expected signs, but were not statistically significant. In other words, major sectoral differences in the way businesses operate in the shadow economy described in the preceding section are lost (except in construction, and trade in model five) when the impact of other characteristics of the businesssuch as size, type of entity, ownership structure, etc.- -are included in the model. This finding bears out the need for designing a strategy and specific measures to formalise the shadow economy that are mainly sector-neutral, apart from for construction.

As we have already presented the most important results in relation to activity sector and other features of business entities, we will now devote more attention to the fourth group: the perceptions and attitudes of business entities to taking part in the shadow economy. Attitudes towards operating in the shadow economy being/ not being justified (a score ranging from 1, no justification, to 5, justified) are statistically significant. The business entities that think that engagement in the shadow economy is 'more justified' are more likely to be engaged in such activities. This is a significant result, as it not only indicates the presence of the view that operating in the shadow economy is perfectly normal for some business entities, but also plays an important role in explaining why entities take part in the informal economy when all other relevant factors are considered. Unlike the justification for operating in the shadow economy, the likelihood of being caught is borderline statistically significant (becoming significant only with a slight change in the specification of model 5, if attitudes on penalties are excluded) (Andrews et al. 2011). The one remaining variable in this group, the dummy variable describing respondents' attitudes to the severity of penalties, is not statistically significant. It is not entirely clear how this variable should affect the results. Companies that claimed penalties are mild do not operate in the shadow economy, but may expect additional protection from unfair competition through stricter sanctions. On the other hand a different interpretation is also possible: that it was the business entities participating in the shadow economy that claimed penalties were mild, which is certainly an incentive to do business in the shadow economy.

\footnotetext{
${ }^{7}$ The use of the logarithm value of turnover in the model did not change the result substantially. Many respondents refused to answer this question, which is why this variable was left out.
} 
Finally, the economic crisis that hit most business entities is not statistically significant (while the values obtained were in line with expectations for the likelihood of taking part in a particular type of activity in the shadow economy). One possible explanation for its insignificance is the duration of the crisis. Another reason could be the fact that it is not only companies with declining turnovers but other businesses as well that turn to the shadow economy to either improve their cash flows or to secure additional sources of financing.

\subsection{Effects of Competition from the Informal Sector}

Competition in the formal sector creates incentives for economic efficiency and is the key driver of economic growth, since it motivates business entities to produce higher quality products at as-low-as-possible cost. On the other hand, as a rule competition between the formal and the informal sectors does not increase productivity and hurts progress in the economy (Perry et al. 2007). The relative cost advantage of business enterprises operating in the informal sector through tax evasion or non-compliance with regulatory requirements enables them to survive even at low levels of productivity. An exception to the adverse impact of competition from the informal sector is a situation where there are substantial barriers to entry, with the informal sector exerting competitive pressure without which the formal sector would face X-inefficiency and waste resources (Loayza et al. 2010). In Serbia, where small business entities are adversely affected by disproportionate tax and regulatory requirements, this positive effect of competition from the shadow economy should also be taken into account.

In this section we analyse the effects of competition from the informal sector due to lower relative costs in relation to business entities operating in the formal economy. In addition to the question of the extent to which informal operation by competitors hurts businesses in the formal sector, another question must be posed: who is hit the hardest, and why?

\subsubsection{Competition from the Informal Sector}

According to the results of the survey, competition from business entities that engage in at least one type of informal activity is extremely widespread. As many as $85.3 \%$ of the business entities surveyed (of those who did respond) felt that there was competition from shadow economy within their sectors (Table 6.12). In some sectors such as transportation and construction nearly all of those surveyed said they faced some form of competition from the shadow economy; these sectors were also those where the majority of the surveyed admitted that they themselves took part in informal activities. Larger business entities, as well as the 'other services' sector, cited slightly lower levels of exposure to this type of competition. 
Table 6.12 Informal sector as competition, obstacles to operation, and loss of revenue by the formal sector (share in number of respondents who answered)

\begin{tabular}{l|l|l|l}
\hline & $\begin{array}{l}\text { Loss of } \\
\text { revenue }(\%)\end{array}$ & $\begin{array}{l}\text { Large or very large } \\
\text { obstacle }(\%)\end{array}$ & $\begin{array}{l}\text { Presence of competition from } \\
\text { shadow economy }(\%)\end{array}$ \\
\hline Total & 27.8 & 34.4 & 85.3 \\
\hline \multicolumn{2}{|l}{ Type of entity } & \multicolumn{2}{l}{} \\
\hline Entrepreneur & 28.5 & 35.2 & 87.9 \\
\hline Business & 26.2 & 32.1 & 79.1 \\
\hline VAT payer & 25.0 & 28.6 & 85.5 \\
\hline $\begin{array}{l}\text { Non-VAT } \\
\text { payer }\end{array}$ & 31.4 & 41.6 & 85.2 \\
\hline
\end{tabular}

Number of employees

\begin{tabular}{l|l|l|l}
\hline Up to 4 & 28.7 & 35.3 & 85.6 \\
\hline $5-19$ & 24.8 & 30.6 & 85.4 \\
\hline 20 and more & 19.4 & 26.7 & 77.7 \\
\hline
\end{tabular}

Participate in the shadow economy

\begin{tabular}{l|l|l|l}
\hline No & 27.0 & 34.7 & 85.3 \\
\hline Yes & 29.6 & 33.7 & 85.3 \\
\hline
\end{tabular}

Sector of economic activity

\begin{tabular}{l|l|l|l}
\hline Agriculture & 23.6 & 46.6 & 82.4 \\
\hline Industry & 29.5 & 34.9 & 85.7 \\
\hline Construction & 37.7 & 49.1 & 96.8 \\
\hline Trade & 26.7 & 26.6 & 88.0 \\
\hline Transportation & 36.0 & 53.8 & 94.2 \\
\hline Catering & 24.7 & 24.0 & 86.8 \\
\hline Other services & 22.5 & 31.2 & 73.8 \\
\hline Region & 28.3 & 37.7 & 80.9 \\
\hline Vojvodina & 26.7 & 36.7 & 81.9 \\
\hline Belgrade & 31.0 & 90.8 \\
\hline Central Serbia & 28.3 & & \\
\hline
\end{tabular}

Source: Own calculations. Survey on Conditions for Doing Business in Serbia, FREN, 2012

Both entrepreneurs and businesses can be considered competition. The findings of the survey show that entrepreneurs mainly compete with other entrepreneurs, while businesses generally do not differentiate between competition from businesses and from entrepreneurs.

\subsubsection{Effects of Competition from the Informal Sector}

Informal activities of competitors are no obstacle to doing business for only $12 \%$ of business entities, while three times as many (34\%) respondents consider them a major obstacle. There is a large difference between different sectors (see Table 6.12), with informal activity particularly an issue in transportation, 
Table 6.13 Informal sector as obstacle to operation

\begin{tabular}{|c|c|}
\hline & Estimated coefficients \\
\hline Entrepreneur & $\begin{array}{l}0.981 \\
(-0.10)\end{array}$ \\
\hline Business & $f$ \\
\hline VAT payer & $\begin{array}{l}0.833 \\
(-1.03)\end{array}$ \\
\hline Non-VAT payer & $f$ \\
\hline Private & $\begin{array}{l}0.636 \\
(-0.57)\end{array}$ \\
\hline Other & $f$ \\
\hline Foreign equity & $\begin{array}{l}0.272^{* *} \\
(-2.29)\end{array}$ \\
\hline Non-foreign & $f$ \\
\hline $\ln$ (employees) & $\begin{array}{l}0.870^{*} \\
(-1.73)\end{array}$ \\
\hline $\ln ($ age $)$ & $\begin{array}{l}1.010 \\
(0.97)\end{array}$ \\
\hline Belgrade & $\begin{array}{l}1.070 \\
(0.31)\end{array}$ \\
\hline Central Serbia & $\begin{array}{l}0.825 \\
(-0.99) \\
\end{array}$ \\
\hline Vojvodina & $f$ \\
\hline Agriculture & $\begin{array}{l}3.837 \\
(1.61)\end{array}$ \\
\hline Industry & $\begin{array}{l}1.180 \\
(0.64)\end{array}$ \\
\hline Construction & $\begin{array}{l}2.348 * * * \\
(2.76)\end{array}$ \\
\hline Trade & $\begin{array}{l}0.911 \\
(-0.44)\end{array}$ \\
\hline Transportation & $\begin{array}{l}2.026^{* * *} \\
(2.48)\end{array}$ \\
\hline Catering & $\begin{array}{l}0.948 \\
(-0.19)\end{array}$ \\
\hline Other services & $f$ \\
\hline Likelihood of detection & $\begin{array}{l}0.408 * * * \\
(-2.75)\end{array}$ \\
\hline Prob $>$ chi $^{2}$ (degree of freedom $)$ & $48.19(15)$ \\
\hline Pseudo $\mathrm{R}^{2}$ & 0.0283 \\
\hline $\mathrm{N}$ (no. of observations) & 825 \\
\hline
\end{tabular}

Notes: $f$-reference variable; ${ }^{*} p<0.10 ; * * p<0.05 ; * * * p<0.01$

agriculture, and construction. The results of an ordered logit model are presented in Table 6.13. We used a question (To what extent are practices of competitors from the informal sector an obstacle to the operation of your company?) as the dependent 
variable. The possible answers ranged from 1 (no obstacle) to 5 (very large obstacle). ${ }^{8}$

The importance accorded to competition from entities operating in the shadow economy is lower for companies with foreign equity, while the type of entity (entrepreneur and VAT payer), legal form, and ownership are not statistically significant. Small businesses (by number of workers) are aware of the existence and importance of informal activity to a greater degree. When viewed by sector of activity, construction and transportation are particularly exposed to competition from the shadow economy. The likelihood of detection is statistically significant: the easier these entities believe it is for informal operations to be detected, the smaller the extent of such competition. ${ }^{9}$ It should be noted that these results are similar to those obtained for South Eastern Europe using the Business Environment and Enterprise Performance Study (BEEPS) database by Hudson et al. (2012).

Some research has concluded that the greatest concerns about corruption from the informal sector are voiced by those entities that most resemble the informal sector. These are small businesses faced with financial constraints that are oriented towards smaller clients, have under-utilised capacities, and operate in a market with low entry costs. ${ }^{10}$ The only part of this conclusion that seems to be applicable in Serbia is that which refers to small businesses, while the greatest problems are present in activities with high entry costs and large participation of unskilled labour. In other words, operating savings - and, consequently, the pressure of competition from the informal sector-are greater in sectors where regulatory obstacles to formalisation are more substantial and where it is more difficult to control workers.

Similarly to the small number of those who believed informal operation was not an issue, a mere $17.8 \%$ of all respondents claimed that unfair competition did not bring about a decline in their annual revenue. On average, lost revenue amounted to $27.8 \%$, affecting particularly the sectors of construction and transportation. In most cases lost revenue amounted to between 10 and $50 \%$ (for about $70 \%$ of all business entities), while $11.6 \%$ of entities estimated that their revenues had been reduced by more than $50 \%$ due to informal competition. It is interesting to note that the estimated loss in revenue $(27.8 \%)$ does not deviate significantly from the estimated share of the shadow economy in GDP as shown in Chap. 5.

In addition to the financial effects reflected in the estimated loss of revenue, we can also cite other consequences of competition from the shadow economy. Respondents primarily mentioned lower turnover and greater difficulty in selling

\footnotetext{
${ }^{8}$ For a similar approach, see Hudson et al. (2012).

${ }^{9} \mathrm{We}$ can obtain similar results when using a dummy variable with the value of 1 in cases where business entities feel that competition from the informal economy is a large or very large obstacle. The key difference lies in the fact that the variable describing whether or not the entity is a VAT payer becomes statistically significant, while the presence of foreign equity and size (measured by number of workers) cease being statistically significant variables.

${ }^{10}$ The findings of the study on the impact of competition from the informal sector in Latin America indicate that sectors with low entry costs cite informal competition as a substantial obstacle (Gonzalez and Lamanna 2007).
} 
products (52\% of all respondents), lower product prices $(41 \%)$, and less investment into technological development due to lower revenue $(14 \%)$. When the data are viewed by sector of activity, price cutting due to unfair competition is slightly more common in construction $(64 \%)$, while lower turnover and greater difficulty in selling products is at its most widespread in trade $(60 \%)$.

\subsubsection{Types of Informal Operation}

The relative cost advantage of business entities in the shadow economy stems from various types of informal operation. Business entities estimate that these types of operation (including not declaring workers, paying wages in cash, and making and receiving informal payments) are represented in their respective sectors of activity to a substantial degree. Thus, only one-quarter of all business entities felt that the practice of not declaring employees is absent from their sector of activity; the same percentage believed that no entities in their sector formally declared lower wages than those actually paid. About half of all respondents felt that up to $50 \%$ of all workers in their sector of activity were either employed informally (without a contract) or declared lower wages (although most respondents believed that the portion of the wage paid in cash generally did not exceed $50 \%$ of the total wage). Finally, about two-thirds of business entities felt that some transactions-up to $50 \%$ of the total-in their sector of activity were made informally (i.e., without paying tax).

In addition to informal operation by registered businesses and entrepreneurs, competition also comes from entities that are not officially registered. The findings of the survey show that about half $(46 \%)$ of all respondents knew of unregistered entities operating in their sector of activity. This view was slightly more common among entrepreneurs than businesses (55\% relative to $37 \%$, respectively) and in the transportation $(78 \%)$ and construction $(67 \%)$ sectors.

Open Access This chapter is distributed under the terms of the Creative Commons Attribution Noncommercial License, which permits any noncommercial use, distribution, and reproduction in any medium, provided the original author(s) and source are credited.

\section{References}

Andrews D, Caldera Sánchez A, Johansson Å (2011) Towards a better understanding of the informal economy. OECD Economics Department Working Papers, No. 873. OECD Publishing

European Commission (2007) Undeclared work in the European Union, Special Eurobarometer Gonzalez AS, Lamanna F (2007) Who fears competition from informal firms? Evidence from Latin America. Policy Research Working Paper Series 4316. The World Bank 
Hanlon M, Mills L, Slemrod J (2007) An empirical examination of corporate tax noncompliance. In: Auerbach A, Hines JR, Slemrod J (eds) Taxing corporate income in the 21st century. Cambridge University Press, Cambridge, pp 140-162

Hosmer D, Lemeshow S (2000) Applied logistic regression, 2nd edn. Wiley, New York

Hudson J, Williams C, Orviska M, Nadin S (2012) Evaluating the impact of the informal economy on businesses in South East Europe: Some lessons from the 2009 World Bank Enterprise Survey. South East Eur J Econ Bus 7(1):99-110

Krstić G, Sanfey P (2011) Earnings inequality and the informal economy: evidence from Serbia. Econ Transit 19(1)

Kyle S et al (2001) The shadow economy in Bulgaria. Harvard University, Agency for Economic Analysis and Forecasting and Institute for Market Economics

Loayza V, Serven L, Sugawara N (2010) Informality in Latin America and the Caribbean. World Bank Policy Research Working Paper Series 4888

Long JS, Freese J (2006) Regression models for categorical dependent variables using Stata, 2nd edn. Stata Press, College Station

Perry G, Maloney W, Arias O, Fajnzylber P, Mason A, Saavedra-Chanduvi J (2007) Informality: exit and exclusion. World Bank, Washington

Putninš TJ, Sauka A (2011) The size and determinants of shadow economies in the Baltic States. Baltic J Econ 11(2)

Rice E (1992) The corporate tax gap: evidence on tax compliance by small corporations. In: Slemrod J (ed) Why people pay taxes: tax compliance and enforcement. University of Michigan Press, Ann Arbor, pp 24-39

Schneider F (eds) (2011a) Handbook on the shadow economy. Edward Elgar, Cheltenham

Schneider F (2011b) The shadow economy in Europe - using payment systems to combat the shadow economy. http://www.bblf.bg/uploads/files/file_378.pdf

Slemrod J (2007) Cheating ourselves: the economics of tax evasion. J Econ Perspect 21(1):25-48

Socio-Economic Council of the Republic of Serbia (2010) Efikasno suzbijanje sive ekonomije, Beograd

Tedds LM (2010) Keeping it off the books: an empirical investigation of firms that engage in tax evasion. Appl Econ 42(19):2459-2473

Williams CC (2006) The hidden enterprise culture: entrepreneurship in the underground economy. Edward Elgar, Cheltenham 